\section{Professor Rob Kerwin}

columns

\section{Formerly Professor} of Clinical

\section{Neuropharmacology at the Institute of Psychiatry and the Maudsley Hospital}

Professor Rob Kerwin died suddenly on 8 February 2007 of unexpected complications of sarcoidosis, an illness which he had suffered for many years. This tragic event has robbed psychiatry of one of the most gifted and talented psychiatric researchers of his generation.

Rob was born in 1955 and grew up in Salford in a working class family - a fact of which he was rightly very proud. His family noticed that he was bright and talented from an early age, a talent he demonstrated by winning a scholarship to Cambridge University to study medicine. After completing his preclinical studies, while his fascination for pharmacology was developing he took time-out to achieve a PhD in 1980 in pharmacology at Bristol University, where he studied dopamine and other neurotransmitters in animal models. He then did some postdoctoral work with the late David Marsden at the Institute of Neurology and after completion of his $\mathrm{PhD}$, he returned to complete his MB BChir in 1984 at Westminster Medical School, where he met his future wife Dr Fiona Lofts. He pursued clinical and research work in cardiology at the Hammersmith Hospital; however, after a brief attachment in neuropsychiatry at the Institute of Neurology, Queen Square in 1986, he entered postgraduate training in psychiatry at the Bethlem Royal and Maudsley Hospital. He not only completed his training in record time (he gained his MRCPsych in 1988 and FRCPsych in 1996) but also by 1989 he had been offered a 'new-blood' senior lectureship at the

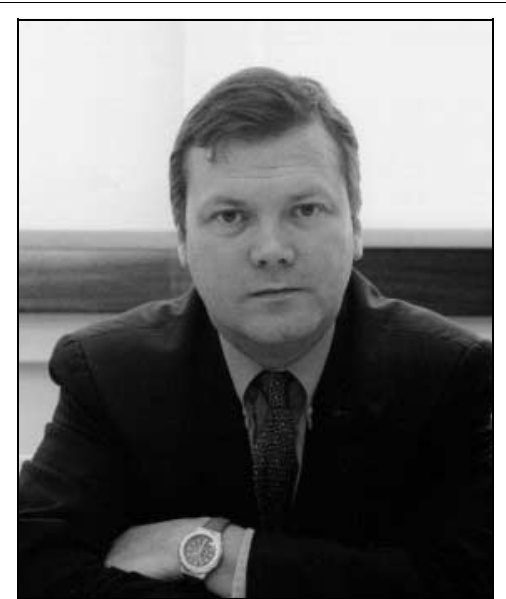

Institute of Psychiatry. By 1995, with the staunch support of the head of the department, Professor Robin Murray, he was awarded a personal chair in Clinical Psychopharmacology and in 1996, the DSC (Lond).

During his years at the Institute of Psychiatry, he was prolific and the size of his research team was constantly growing. His research was broad but shared a common theme of understanding the neurobiological basis of schizophrenia, always with a view towards improving treatment. His first significant work was with me on changes in morphology and receptor binding in postmortem brain tissue. He and his then training fellow, Lyn Pilowsky, later made use of neuroreceptor ligand studies using single-photon emission computed tomography (SPECT) to image and map dopamine, GABA and serotonin receptor subtypes in the brains of healthy volunteers and patients. This clarified the unique effectiveness and side-effect profile of the drug clozapine in otherwise treatment-resistant patients as a result of its limbic selectivity. This body of work earned him the Joel Elkes International Award for Psychopharmacology. In his more recent work with Maria Arranz, he used allelic association pharmacogenetic techniques to predict response to pharmacological agents. This strand has had important commercial applications and has given rise to a spin-off company called Theragenetics.

Clinically, Rob remained very active and was one of the architects of the National Psychosis Unit at the Bethlem Royal Hospital. This patient population inspired his research, especially into predictors of treatment response. This clinical service won the national Hospital Doctor Psychiatry Team of the Year Award.

Outside of work, Rob was a dedicated family man and applied the same degree of passion to his hobbies and pursuits as he did to his research. For instance, from his university days, Rob was a keen rower and made the annual pilgrimage to Henley rowing regatta. In addition, he obtained a flying licence, as he loved flying light aircrafts, and he often extended the invitation to colleagues - although there were few takers! Sadly, his flying days came to an end with the onset of ill health. The sarcoidosis was accompanied by complications resulting in hip replacement and cardiac procedures, but he endured these with stoic acceptance. He was determined not to let them stop him from working or to noticeably distress him. He was a private man, often shy, but loyal to his friends. He was not inhibited in letting you know his views, especially the shortcomings of 'incompetent' bureaucracies.

His papers and work regarding the pathological mechanisms and developing treatments for those affected by mental illness will leave a rich legacy that will continue to be appreciated. He will be sorely missed, not only by his colleagues but also especially by Fiona, his wife, and his three wonderful daughters.

Ian Everall

doi: 10.1192/pb.bp.107.016675 